\title{
Immunmoduláló antitestek alkalmazása - az onkológia új fejezete
}

\author{
Szamosi Szilvia dr. ${ }^{1}$ - Váróczy László dr. ${ }^{2}$ - Szekanecz Zoltán dr. ${ }^{1}$ \\ Debreceni Egyetem, Általános Orvostudományi Kar, Belgyógyászati Intézet, \\ ${ }^{1}$ Reumatológiai Tanszék, ${ }^{2}$ Hematológiai Tanszék, Debrecen
}

\begin{abstract}
Az utóbbi 10 évben robbanásszerű fejlődés következett be a tumorimmunológiai kutatások területén. A T-sejtes antigén-felismerés lépéseinek és az ezeket szabályozó mechanizmusoknak a megismerése vezetett az új immunterápiás szerek megjelenéséhez, amelyeket ma már sikerrel alkalmaznak bizonyos szolid tumorok és hematológiai malignitások kezelésében. A szerzők jelen közleményben az immunmoduláló antitestekre, az „immune checkpoint” gátló terápiára fókuszálnak. Az első ilyen, klinikumban is alkalmazott gyógyszer a citotoxikus T-lymphocyta-antigén-4(CTLA-4-) inhibitor terápia volt. Az ipilimumabot a klinikai vizsgálatok ígéretes eredményei alapján 201 1-ben - először az Egyesült Államokban, nem sokkal később Európában - regisztrálták a kiterjedt melanoma másod- (2011), majd első vonalbeli kezelésére (2013). A CTLA-4-inhibitor molekulát követően további, az immunrendszer múködését szabályozó antitestek kipróbálása következett. A programozott sejthalál-1 (PD-1) útvonalon ható, blokkoló antitestek alkalmazása több tumoros indikációban jelentős daganatellenes immunválaszt eredményez. A PD-1 receptorgátló antitestek közül a nivolumab alkalmazásával számos daganattípus esetében sikerült tartós, objektív tumorválaszt elérni, így áttétes melanoma, nem kissejtes tüdőrák kezelésére a nivolumab a terápiás arzenál részét képezi. A kedvező daganatellenes aktivitás mellett számolni kell a fenti kezelések - legtöbb esetben reverzibilis - mellékhatásaival, amelyek az általuk létrehozott nem specifikus immunaktivációval hozhatók összefüggésbe. A jövőben számos, még megválaszolatlan kérdésre adhatnak választ a folyamatban lévő és a tervezett klinikai kutatások. A kezelés hatékonyságának előrejelzésére szolgálhatnak a PD-Ll-expresszión túl további új, eddig nem azonosított biomarkerek is. Intenzív kutatás tárgyát képezi az, hogy az immunterápiás kezelésre milyen más daganatfajták adhatnak megfelelő terápiás választ. Az immunmoduláló antitestek egymással vagy más daganatellenes, kemo- vagy célzott terápiával való kombinációja javíthatja a kezelés hatékonyságát, de ezek szélesebb körben való elfogadásához további klinikai vizsgálatok szükségesek. Orv. Hetil., 2016, 157(Szuppl. 2), 9-16.
\end{abstract}

Kulcsszavak: immunoonkológia, immunmoduláló antitest, CTLA-4, PD-1

\section{Application of immunomodulatory therapeutic antibodies - a new perspective in oncology}

In the past decade major advances in tumor immunology, a better understanding of antigen recognition by T-cells likewise discovering the regulatory inhibitory signals resulted in the development of new immunotherapies with promising durable responses in various solid tumor types and in hematologic malignancies. This review focuses on immunomodulatory antibodies, namely immune checkpoint inhibitor therapy. The prototype of this new class of immune stimulating agents was cytotoxic T-lymphocyte antigen-4 (CTLA-4) antagonists. After demonstrating enhanced survival, ipilimumab was approved first in the United States in 2011, further on in the European Union for second-line (2011) and for first-line therapy (2013) of metastatic melanoma. Additional T-cell intrinsic pathways were identified and targeted for clinical development. Antibodies blocking the PD-1 pathway also showed promising clinical activity and objective tumor response in several types of tumors, including metastatic melanoma, non-smallcell lung cancer. On the other hand antitumor activity is frequently accompanied by significant reversible immunerelated adverse events. To explore potential new immune checkpoint targets bring forth several challanges. Future clinical development will involve identifying potential biomarkers anticipating responsiveness to pathway blockade and additional tumor types likely to respond to the therapy. Furthermore, combination strategies, immune checkpoint inhibitors combined with cancer vaccines, targeted inhibitors and traditional chemotherapies are being evaluated in pre-clinical studies. 
Keywords: immuno-oncology, immunomodulatory antibodies, CTLA-4, PD-1

Szamosi, Sz., Váróczy, L., Szekanecz Z. [Application of immunomodulatory therapeutic antibodies - a new perspective in oncology]. Orv. Hetil., 2016, 157(Suppl. 2), 9-16.

(Beérkezett: 2016. április 11.; elfogadva: 2016. április 27.)

\section{Rövidítések}

AHSCT = autológ őssejt-transzplantáció; ALK = anaplasticus lymphoma kináz; APC = antigén-prezentáló sejtek; $\mathrm{CR}=$ komplett remisszió; $\mathrm{CTL}=$ citotoxikus T-lymphocyta; CTLA-4 = citotoxikus T-lymphocyta-antigén- 4 ; DTIC $=$ dakarbazin; EBV = Ebstein-Barr-vírus; EMA = Európai Gyógyszerügynökség; FDA = Amerikai Élelmiszer- és Gyógyszerfelügyelet; GVHD = graft versus host betegség; ICOS = indukálható kostimulátor; IFN- $\gamma=$ interferon-gamma; irAE = (immune-related adverse effect) immunrendszeri eredetű mellékhatás; LAG-3 = lymphocytaaktivációs gén-3; LMP = latent membrane protein; $\mathrm{MHC}=$ major hisztokompatibilitási komplex; NK = természetes ölő; NSCLC = nem kissejtes tüdőrák; $\mathrm{OR}=$ (objective response) objektív válaszadás; $\mathrm{OS}=($ overall survival) teljes túlélés; PD-1 = programozott sejthalál-1; PD$\mathrm{Ll}=$ programozott sejthalál-1 ligand; PFS $=($ progression-free survival) medián progressziómentes túlélés; $\mathrm{PR}=$ (partial remission) részleges remisszió; RECIST $=$ (response evaluation criteria in solid tumors) válaszadást értékelő kritériumok szolid tumoros betegeknél; STAT3 = signal transducer and activator of transcription; TCR $=$ T-sejt-receptor; TGF- $\beta=$ transzformáló növekedési faktor béta; TKI = tirozinkináz-inhibitor; TNF = tumornekrózis-faktor; Treg = regulatorikus T-sejt; $\mathrm{WHO}=$ (World Health Organization) Egészségügyi Világszervezet

Az utóbbi néhány évben a tumorkutatás területén jelentős előrelépést jelentett azoknak a komplex molekuláris immunológiai mechanizmusoknak a felderítése, amelyek a daganatos sejtek elleni immunválaszt regulálják. A tumorok azonban számos olyan kibúvó mechanizmust fejlesztenek ki, amelyek segítségével az ellenük létrejövő fiziológiás immunválaszt megkerülhetik vagy visszaszoríthatják, és ez a daganat további növekedését, invázióját teszi lehetôvé. Az új gyógyszerek - amelyek felszabadítják az immunrendszert a gátlóhatás alól és lehetővé teszik, hogy a daganatok ellen hatékony immunválasz alakuljon ki - közös neve immunmoduláló antitestek vagy immune checkpoint inhibitorok.

\section{A fiziológiás tumorellenes T-sejt-választ szabályozó folyamatok}

A tumorsejtek elleni immunválaszban a veleszületett és az adaptív immunrendszernek egyaránt fontos szerepe van. A kóros, daganatos sejtek eliminációjának kezdeti lépéseként az innate immunrendszer sejtjei aktiválódnak. Az interferon-gamma (IFN- $\gamma$ ) útvonalon indukált macrophagok által szekretált citokinek, kemokinek és nitro- gén-oxid a kóros sejteket elpusztítják. A természetes ölősejtek (NK-sejtek) számos olyan aktiváló és gátló receptort expresszálnak, amelyek segítségével képesek megkülönböztetni a kóros és normális sejteket, és ezenfelül a dendritikus sejtek érését elősegító citokineket is termelnek. Az NK-sejtek és a macrophagok által előidézett tumorlízis olyan új, tumorasszociált antigének keletkezéséhez vezet, amelyeket a továbbiakban az antigénprezentáló sejtek (APC) dolgoznak fel és mutatják be, ezzel aktiválva és megteremtve a kapcsolatot az adaptív immunrendszer sejtjeivel $[1,2]$. Ha sikeresen megtörtént a T-sejt aktivációja, érése, a klonális proliferációt követően a tumoros szövetben részben a citotoxikus T-sejtek (CTL), részben pedig az aktivált B-sejtek által termelt antitestek révén az adaptív immunitás is jelentős szerepet játszik a daganatok elpusztításában [3].

A T-sejtek aktivációjához két szignál szükséges: az MHC-molekulákon prezentált antigén és egy második, kostimulációs szignál is, amelynek hiányában a T-sejtreceptor (TCR) stimulálása válaszképtelenséget okoz. A kostimulációs molekulák közül kiemelkedő jelentőségúek a B7 molekulacsalád tagjai, ezen belül is a CD80 (B7-1) és CD86 (B7-2), amelyet az aktivált APC-k expresszálnak. Ezek, hozzákötődve a T-lymphocyták CD28 receptorához, a naiv T-sejteket aktiválják. A CD28-cal szerkezeti hasonlóságot mutató citotoxikus T-lymphocyta-asszociált protein-4 (CTLA-4) fiziológiás gátló receptorként múköodik, amely intracelluláris lokalizációjú, majd aktivációt követően kerül a sejtfelszínre. Kivételt képeznek a karmesterként múködő regulatorikus T-sejtek (Treg), ahol a CTLA-4 konstitutív expressziót mutat, lehetôvé téve az immunszuppresszív hatás kifejtését. A T-sejt-aktiváció CTLA-4-közvetített gátlása komplex folyamatok eredője; részben a CD28 általi aktiváció gátlásával, illetve direkt gátló szignalizáció elindításával valósulhat meg $[4,5]$. A CTLA-4 negatív szabályozó szerepét mutatja az a felfokozott T-sejt-aktiváció, amelyet CTLA-4-hiányos egerek esetében tapasztalunk letális immun-hiperaktiváció klinikai képében [6].

Már jóval korábban, 1992-ben leírták a programozott sejthalál-1 (PD-1) molekula szerepét a thymusban történő negatív T-sejt-szelekcióban. Azonban a PD-1 és PD-2 ligandját (PD-L1 vagy CD274, PD-L2 vagy CD273) és annak immunológiai checkpoint funkcióját csak a 2000-es években fedezték fel. Ezek szintén a B7 molekulacsalád tagjai, és gyulladásos citokinek hatására a dendritikus sejtek, macrophagok mellett az epithelialis és endothelialis sejtek is expresszálják, de a PD-Ll számos 
tumorsejten is kifejeződik. Receptoruk a PD-1 (CD279) az aktivált T-lymphocytákon, a B-, NK- és a myeloid sejteken is megtalálható, valamint a tumorinfiltráló lymphocytákon is megjelenik ez a koinhibitoros receptor. A PD-1/PD-Ll, hasonlóan a CTLA-4/CD80, 86 kölcsönhatáshoz, szintén gátló jellegű és fontos szerepe van az immunválasz szabályozásában, a perifériás tolerancia kialakításában [7].

Mégis miért nem képes az immunrendszer hatékonyan eliminálni a daganatos sejteket? Egyik oka az, hogy a T-sejt-aktiváció során a megerősítő, aktiváló jelátvitel mellett gátló mechanizmusok is múködésbe lépnek fiziológiás körülmények között, amelyeknek szerepe van a tolerancia fenntartásában és az autoimmunitás kialakulásának megelózésében. Ugyanakkor ezek az úgynevezett gátló checkpointok a hatékony tumorellenes immunválasz létrejöttét is megakadályozzák. Emellett maguk a tumoros sejtek is igyekeznek különféle kibúvókat találni az immunrendszer elől, vagy elnyomni az ellenük irányuló immunválaszt. A daganatok felismerése lehetetlenné válik, ha a tumorok antigén-prezentációja gátolt, de gyakran immunszuppresszív faktorok (TGF- $\beta$ ) termelésével is csökkentik az ellenük irányuló immunválaszt. A Treg-sejtek toborzásával és befolyásolásával, valamint kihasználva az immune checkpoint útvonalak gátló funkcióját, a tumoroknak további menekülési lehetőségük nyílik, és a fenti, úgynevezett „escape” mechanizmusok akár egy időben is múködésbe léphetnek [8]. Látván ezt a szoros, de dinamikus kölcsönhatást a daganatok és az immunrendszer között, érthető, hogy miért került az immunrendszer a tumorellenes kutatások fókuszába. Immunterápiák alkalmazására daganatos betegségekben korábban is történtek kísérletek, és hosszú evolúció vezetett ahhoz, hogy klinikai fázisban alkalmazva ezek a szerek tartós, hosszú távú eredményt hoztak a daganatos betegségek kezelésében. Ha visszatekintünk a kezdeti időszakra, az első elképzelés az volt, hogy vakcináció útján lehetne stimulálni az immunrendszert, hogy ezáltal a daganatos sejteket képes legyen elpusztítani. Több tanulmányban is próbálkoztak bizonyos peptidek, módosított tumorsejtek, dendritikus sejtek, rekombináns virális vagy bakteriális vakcinák adásával, azonban objektív klinikai válasz hiányában ezek a kísérletek megbuktak. A sikertelenség oka multifaktoriális, többek között a nem megfelelő antigén kiválasztása, a kostimuláció létrejöttének elmaradása vagy végső soron a tumorreaktív T-sejtek funkcionális inaktivációja, immuntolerancia kialakulása miatt hiúsult meg a hatékony daganatellenes immunválasz [9].

\section{A CTLA-4, az első checkpoint inhibitor}

Az 1980-as évek végén a kostimuláció részletesebb megismerésével, majd a '90-es évek közepén a negatív szignalizáció, a CTLA-4 inhibíciós szerepének felfedezésével már egy új út nyílt meg a daganatok immunterápiájában.
A CTLA-4-blokád sikere azért is számított nagyon ígéretesnek, mert itt a célpontok nem a tumorsejteken, hanem a T-sejteken lévő molekulák voltak, így elviekben a különböző szövettani formák és genetikai defektusok nem befolyásolják az eredményt. Emellett a T-sejtek fokozott kostimulációja különböző egérmodellekben a tumorvakcinák hatását is képes volt potenciálni, vagy lokális irradiációval, cryoablatióval kombinálva egy szisztémás tumorellenes immunválaszt provokálva akár a távoli metasztázisok eradikációjában is sikeresen alkalmazhatók [10]. Az állatkísérletes eredmények után egyenes út vezetett a CTLA-4-blokád klinikai kutatásokban, majd gyakorlatban történő alkalmazásához. A humán CTLA4-ellenes antitest ipilimumab alkalmazásával több fázis I/II vizsgálatban a tumor regresszióját figyelték meg különböző tumortípusokban, így melanomában, vesesejtes és prostatacarcinomában, urothelialis és ovariumból kiinduló daganatokban $[11,12]$. Két fázis III vizsgálatot is végeztek prostatacarcinomában szenvedő betegeknél [12], ahol ugyan az alcsoport-analízisek az ipilimumab hatékonyságát bizonyították, elsősorban a jobb prognózisú, májmetasztázisokkal nem rendelkező betegekben, de a betegek túlélésében a javulás mértéke nem volt statisztikailag szignifikáns. A korai fázisú vizsgálatokban a CTLA-4-gátlással kapcsolatba hozható immunológiai toxicitás viszonylag magas arányban, mintegy 25-30\%ban fordult elő, elsősorban a gyorsan regenerálódó vastagbél-nyálkahártyát és bőrt érintő colitis, dermatitis képében, ritkábban hepatitis, pancreatitis, pneumonitis vagy hypophysitis jelentkezett $[13,14]$.

\section{Ipilimumabkezelés melanomában}

Két, fázis III vizsgálatban előrehaladott, egyéb kemoterápiás kezelésre nem reagáló, melanomás betegek bevonása mellett vizsgálták az ipilimumab hatékonyságát [10]. Az első, mérföldkőnek számító fázis III vizsgálat szignifikáns túlélési előnyt hozott az ipilimumabbal kezelt betegek esetében. A 676, nem reszekábilis III-as, illetve IV-es stádiumú, előzetes kezelésben részesült, melanomás beteg bevonásával végzett randomizált vizsgálatban az önmagában, illetve gpl00 peptid vakcinával kombinációban adott ipilimumabot ( 3 hetente $3 \mathrm{mg} / \mathrm{kg}$ dózisban adagolva) az önmagában adott gpl00 peptid vakcinával hasonlították össze. A legjobb objektív válaszarányt az egyedüli szerként ipilimumabot kapott csoportban mérték (10,9\% vs. 5,7\% az ipilimumab + gpl00 és $1,5 \%$ a gpl00 karon). A teljes túlélésben nem volt szignifikáns különbség a két, ipilimumabot kapó kar között (medián: 10,1, illetve 10,0 hónap), és mindkettő meghaladta a gpl00-kar medián értékét (6,4 hónap). A két ipilimumabkaron 10-15\% volt a súlyos (grade 3-4), az immunrendszerrel összefüggő mellékhatások (irAE) aránya, és 14, kezeléssel összefüggő halálesetet is regisztráltak $(2,1 \%)$, amelyből 7 volt immunológiai eredetü [10]. 
Egy másik, randomizált fázis III vizsgálatban 502, előzetes kezelésben nem részesült, áttétes (stage III, illetve IV) melanomás beteg részesült ipilimumabbal kombinált ( $10 \mathrm{mg} / \mathrm{kg}^{*} 3$ hetente*) dakarbazin (DTIC), illetve DTIC + placebo kezelésben [15]. A kezelésre adott válasz aránya $(\mathrm{CR}+\mathrm{PR}) 15,2 \%$ vs. $10,3 \%$ volt az ipilimumabot is, illetve csak dakarbazint kapók között ( $\mathrm{p}=$ 0,09), és szignifikáns különbséget találtak a két csoport túlélésében (11,2 hónap vs. 9,1 hónap). Súlyos immunasszociált mellékhatások az ipilimumabot tartalmazó karon 38,1\%-ban fordultak elö, és - a fent említett vizsgálattól eltérôen - a leggyakrabban a májat érintették (hepatitis). A vizsgálat 5 éves túlélési adatai alapján az ipilimumab-DTIC kar betegeinek túlélése közel 10\%-kal meghaladta a placebo-DTIC kar betegeinek túlélését, $18,2 \%$ vs. $8,8 \%$ [16].

Óriási sikerként könyvelhető el, hogy bizonyos betegeknél egy relatíve rövid időtartamú (4 dózisban adott 3 $\mathrm{mg} / \mathrm{ttkg} 3$ hónap alatt) ipilimumabkezelést követően hosszú távú - akár 10 éves - túlélést sikerült elérni [17]. Ennek magyarázatául szolgálhat az az elképzelés, hogy az immunterápiák átállítják és újratanítják az immunrendszert, hogy képes legyen a tumort állandó ellenőrzés alatt tartani. Az ipilimumabot a fenti klinikai vizsgálatok eredményei alapján 2011-ben - először az Egyesült Államokban, nem sokkal később az Európai Unióban is regisztrálták a kiterjedt melanoma másod- (2011), majd első vonalbeli kezelésére (2013). Egyelőre nem ismerjük azokat a terápiás döntéshozást megkönnyítő biomarkereket vagy egyéb predikciós tényezőket, amelyek az antiCTLA-4-terápiára adott klinikai választ előre jeleznék.

Egy másik megemlítendő különbség a konvencionális kemoterápiához képest az ipilimumab farmakokinetikája. Míg a hagyományos kemoterápiákra vagy a molekulárisan célzott tirozinkináz-inhibitorokra adott válasz már a kezelést követő néhány héten belül megmutatkozik, az immunmoduláló antitestek esetében sokkal lassabban (akár 6 hónap) alakul ki. A kezelést követő kezdeti időszakban több esetben megfigyelhető a képalkotó vizsgálattal követett agyi metasztázisok méretének növekedése, amely feltehetőleg az immunsejtek infiltrációjával hozható összefüggésbe. Ebből következik, hogy az onkológiai gyakorlatban megszokott objektív hagyományos válaszadási mutatókat (WHO vagy RECIST: traditional response evaluation criteria in solid tumors) itt nem alkalmazhatjuk, az immunterápiák esetében új, úgynevezett immunfüggő válasz kritériumrendszert (immune-related response criteria - irRC) kell megfogalmazni. Ennek ismeretében elkerülhető, hogy a checkpointot gátló terápiát tévesen, túl korán megszakítsuk feltételezett hatástalanság miatt [18].

\footnotetext{
* EMA által jóváhagyott dózis: $3 \mathrm{mg} / \mathrm{ttkg}$ minden 3. héten, összesen 4 dózisban.
}

\section{PD-1 - PD-L1}

A CTLA-4-gátlás klinikai sikere valóban új fejezetet nyitott az immunoonkológia területén, így kézenfekvő volt, hogy találjanak egyéb, a T-sejtek jelátviteli folyamataiban és aktivációjában fontos targetet, amely lehetővé teszi újabb immunmoduláló antitestek kifejlesztését. Állatkísérletekben a PD-Ll a T-sejtek apoptózisát iniciálva a tumorsejtek túlélését segítette [19]. A tumorok mikrokörnyezetében a korai T-sejt-aktiváció során a PD-1/ PD-Ll interakciónak hasonló gátló szerepe van az effektor T-sejtekre, mint a CTLA-4/B7 interakciónak. A PD1-blokád azonban nemcsak az effektor T-sejtek aktivitását potencírozza, hanem az NK-sejtek aktivitását is a tumorok környezetében, illetve a tumorspecifikus T-sejtek anergiáját is képes feloldani. A PD-1-útvonal gátlásával tehát egy sokkal komplexebb, több immunológiai útvonalat is involváló tumorellenes kontrollt érhetünk el.

A PD-Ll-expresszió mértéke igen különböző lehet az egyes tumorok esetében, melanomában, petefészek- és tüdődaganatok esetében, valamint a tumorok mikrokörnyezetében lévő myeloid sejteken találtak magas PD-Llexpressziót [20]. Ahhoz, hogy a heterogenitás okát megértsük és a PD-1-ligandot esetleges biomarkerként használni tudjuk, meg kell ismernünk azokat a szignálokat, amelyek a tumorsejtek PD-Ll-expressziójának indukciójában szerepet játszanak. Ezek a veleszületett és az adaptív immunrezisztencia, amely nem azonos a veleszületett és adaptív immunitás fogalmával. Bizonyos tumorok, mint például a glioblastoma vagy bizonyos lymphomák, tüdőtumorok esetén egy konstitutív onkogén szignál (ALK, STAT3) biztosítja a tumorsejtek PD-Llexpresszióját, függetlenül attól, hogy a tumor mikrokörnyezetében milyen gyulladásos szignalizáció zajlik. Az adaptív immunrezisztencia esetében a PD-Ll-expresszió már az aktív, tumorellenes immunválasz része, amelyet a tumor közvetlen környezetét infiltráló lymphocyták aktivációja és interferon-gamma- (IFN- $\gamma^{-}$) termelése indít el. Így láthatjuk, hogy előrehaladott tumorok esetén is aktív „immunsurveillance”, azaz immunológiai ellenőrző funkció múködik, amely alól a daganatos sejtek próbálnak kibújni az inhibitoros receptor-ligand fokozott expressziója útján (1. ábra). Az állatkísérletes adatok, tumoros egérmodellek is számos evidenciát szolgáltattak arra nézve, hogy PD-1 vagy PD-1-ligand blokkolása felerősíti a tumorok környezetében a tumorellenes immunválaszt [21].

Fázis I-es vizsgálatokban a humán $\mathrm{IgG}_{4} \mathrm{PD}$-1-antitest alkalmazásával Hodgkin-lymphomában [22], melanomában [23], valamint colon-, hólyag- és vesesejtes rákban [24], nem kissejtes tüdődaganatokban a betegek egy részében komplett, illetve parciális regressziót sikerült elérni [20], azonban ezzel egyidejúleg a metasztázisok fokozott lymphocytás infiltrációját is megfigyelték. A tanulmányokban részt vevő jó válaszadók 2 éves követése során tartós remissziót írtak le, amely az utolsó terápiás ciklust követően 1 évvel később is fennmaradt. Súlyos 
A) innate immunrezisztencia

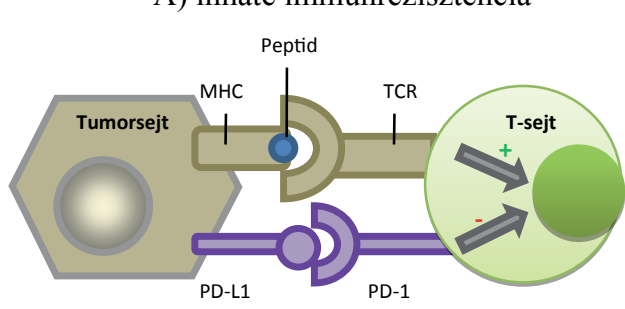

Konstitutív onkogén szignalizáció

B) adaptív immunrezisztencia
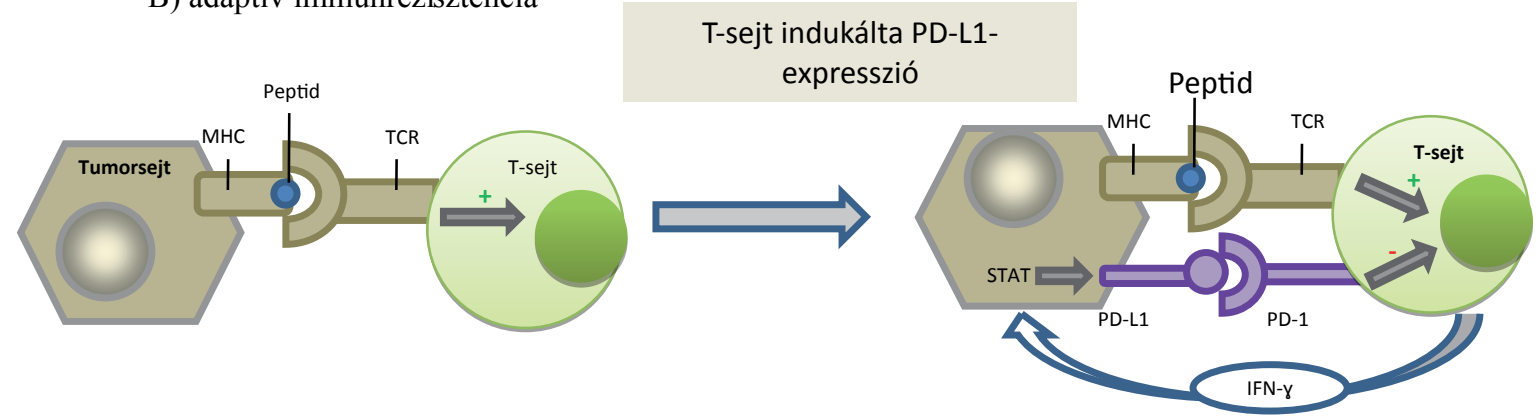

1. ábra

| A tumorsejtek PD-L1-expressziójának különböző útjai

immunológiai toxicitás az anti-PD-1-terápia mellett jóval kisebb arányban fordult elő, mint a CTLA-4-gátlók esetében, amely hasonló volt az ipilimumab fentebb részletezett mellékhatásához [11]. A PD-1-ellenes antitestek közül a nivolumabot az FDA 2014 decemberében, az EMA 2015 júniusában metasztatikus melanoma, míg laphámtípusú előrehaladott vagy metasztatikus nem kissejtes tüdőrák kezelésére az FDA 2015 márciusában, az EMA 2015 júliusában fogadta el. A pembrolizumabot metasztatikus melanoma kezelésére az FDA 2014 szeptemberében, míg az EMA 2015 júliusában fogadta el, majd az FDA 2015 októberében olyan előrehaladott vagy metasztatikus nem kissejtes tüdőrákban szenvedő betegek kezelésére is engedélyezte korábbi kemoterápia után, akiknek a tumora PD-Ll-et expresszál.

\section{PD-1-gátló kezelés melanomában}

Pembrolizumabbal több vizsgálat is történt ipilimumabnaiv és előzőleg kezelt betegek körében. Fázis I-es vizsgálatban 655 beteget 3 -féle kezelési terv alapján (10 $\mathrm{mg} / \mathrm{kg}$ pembrolizumab 2 hetente, $10 \mathrm{mg} / \mathrm{kg}$ pembrolizumab 3 hetente, illetve $2 \mathrm{mg} / \mathrm{kg} 3$ hetente 4 alkalommal) randomizáltak. A betegek 75\%-a kapott korábban sikertelenül egyéb szisztémás kezelést, $52 \%$-uk ipilimumabot. Mind a RECIST kritérium, mind pedig az irRC 33\%-os volt, e tekintetben a 3 karban nem volt különbség. A 6 hónapos progressziómentes túlélés egyenként $47,3 \%, 46,4 \%$ és $26,5 \%$ volt, a 12 hónapos túlélés $74,1 \%, 68,4 \%$ és $58,2 \%$ volt a különböző karokban. Itt a korábbi preklinikai vizsgálatok során prediktív markerként számon tartott PD-Ll-expresszió nem mutatott összefüggést a klinikai válaszadással. A kezeléssel össze- függő toxicitás enyhébb, kezelhető formában jelentkezett, a betegek $83 \%$-a számolt be legalább egy adverz eseményről. Leggyakrabban fáradtság, bőrviszketés, bőrpír, hasmenés, arthralgia jelentkezett [25]. A pozitív eredmények után két, fázis II-es vizsgálatot végeztek, ipilimumabrefrakter és -naiv betegeken. 540 ipilimumabrefrakter beteget 3 karba soroltak $(2 \mathrm{mg} / \mathrm{kg}$ pembrolizumab 3 hetente, $10 \mathrm{mg} / \mathrm{kg}$ pembrolizumab 3 hetente és hagyományos kemoterápia). A 6 hónap után az egyes karokban a betegek progressziómentes arányai sorrendben 34, 38 és 16\%-os volt, az objektív válaszadási ráta 21,25 és $4 \%$ volt [26].

A nivolumabdózis-kereső fázis I/II-es vizsgálatban 107 előrehaladott melanomás beteget kezeltek kéthetente adott $0,1-10 \mathrm{mg} / \mathrm{kg}$ dózissal 96 héten át. A betegek összesített átlagos túlélése 16,8 hónap volt, és az 1 és 2 éves túlélési arány $62 \%$ és $43 \%$ volt. Komplett vagy parciális választ a melanomás betegek 31\%-a mutatott [27]. A korai fázisú klinikai vizsgálatok pozitív eredményeit további három, fázis III vizsgálat követte. A CheckMate 066 vizsgálatba 418, előzőleg kezeletlen, BRAF vad típusú melanomás beteg került bevonásra. Az egyik karon kéthetente $3 \mathrm{mg} / \mathrm{kg}$ nivolumabot, a másikban 3 hetente $1000 \mathrm{mg} / \mathrm{m}^{2}$ dakarbazint kaptak. A fenti karokban egyenként 73 és $42 \%$-os volt az 1 éves túlélési arány, és a válaszadási ráta is magasabb volt a nivolumabcsoportban (40\% vs. 14\%) [23]. A Checkpoint 037 vizsgálatba 405 olyan nem reszekábilis vagy metasztatikus melanomás beteget vontak be, akik ipilimumabkezelést követően vagy BRAF $V^{600}$-mutációt hordozó betegek esetében $i p i$ limumab- és BRAF-inhibitor terápiát követően progrediáltak. Ebben a betegcsoportban is szignifikánsan jobb eredményt értek el a nivolumabkaron a kemoterápiával 
összehasonlítva. Az objektív válaszadás a nivolumabkezelési karon 32\%, míg a kemoterápiás karon 10\% volt [28]. A CheckMate 067 vizsgálatba 945, korábban kezelésben nem részesült, nem reszekábilis vagy metasztatikus melanomás beteget randomizáltak, nivolumab vagy ipilimumab monoterápiás, illetve nivolumab plusz ipilimumab kombinációs kezelési karra. A nivolumab önállóan vagy kombinációban is hatékonyabbnak bizonyult az ipilimumabhoz képest (medián progressziómentes túlélés [PFS] 6,9 hónap, illetve 11,5 hónap és 2,9 hónap volt). Az objektív válaszadási ráta 58,44 és 19\%-os volt, a legmagasabb a kombináció esetén, majd a nivolumabés ipilimumabkarban. A terápia megszakítását indokló súlyos adverz események gyakrabban fordultak elő a kombinációs terápia mellett (ipilimumab plusz nivolumab 36,4\%, nivolumab 7,7\% és ipilimumab 14,8\%) [29].

\section{PD-1-gátló kezelés nem kissejtes tüdőrákban}

A tüdődaganat világszerte a legmagasabb incidenciával és mortalitási mutatókkal jellemezhető daganatféleség, emellett az összes daganatos halálozás 18\%-áért felelős. A nem kissejtes tüdőrák (NSCLC) 80-85\%-át teszi ki az összes tüdődaganatnak, és sajnos 70\%-ban már előrehaladott, inoperábilis stádiumban kerül felismerésre. $\mathrm{Az}$ első vonalban alkalmazott platinaalapú kemoterápiák mellett mintegy 10-12 hónapos medián túlélés várható, amely a tirozinkináz-inhibitorok bevezetésével sem javult. Míg az anti-CTLA-4-antitest-terápia hatékonyságát NSCLC esetén ez idáig nem sikerült bizonyítani, a PD-1/PD-Ll útvonal gátlása a teljes túlélés (OS) és a hosszú távú túlélés tekintetében is jó eredményeket mutatott [30]. Egy fázis III, nyílt elrendezésű, multicentrikus, randomizált vizsgálatba 272 metasztatizáló laphámsejtes NSCLC-s beteget vontak be, akik nivolumab-vagy docetaxelterápiát kaptak másodvonalban [31]. Az elsődleges végpont a teljes túlélés volt. A terápia megkezdésétől számított egy év múlva a nivolumabcsoportban a betegek 42\%-a élt, míg a docetaxelcsoportban 24\%-a. A medián OS 9,2 (nivolumab) versus 6 hónap (docetaxel) volt, így a fázis III vizsgálatok után az EMA 2015. július 20-án elfogadta a nivolumabot a platinabázisú kemoterápiára refrakter laphámsejtes NSCLC kezelésére. A CheckMate 017-es törzskönyvező vizsgálatban a kezeléssel összefüggő mellékhatások aránya alacsonyabb volt a nivolumabkaron (58\%), ebból 3 , illetve 4 súlyosságú mellékhatás 7\%-ban fordult elö, a docetaxel esetében ezek az értékek $86 \%$ (minden súlyossági fokozat) és 55\% (3/4 fokozat) voltak. Több vizsgálat célpontja volt a PDL-1-expresszió potenciális biomarkerként való azonosítása. A nivolumab esetén laphámsejtes tüdőcarcinomában a túlélési előnyt attól függetlenül is megfigyelték, hogy a betegeknek immunhisztokémiai vizsgálattal igazolt PD-Ll-pozitív vagy -negatív tumora volt (a tumormembrán-expressziós határérték 1\%, 5\% vagy 10\%) [32].
A PD-L1-, PD-L2-expresszió önálló prediktív markerként való alkalmazása kérdéses, további vizsgálatokat igényel [31].

\section{PD-1-gátló kezelés Hodgkin-lymphomában és egyéb hematológiai malignitások esetén}

Hodgkin-lymphomában a malignusan elfajult nyirokcsomók szövettani vizsgálata során jellegzetes megjelenésű Reed-Sternberg-sejteket lehet detektálni, amelyek B-sejtes eredete csak nemrégiben vált nyilvánvalóvá. A valódi daganatsejtek aránya azonban meglehetősen alacsony, a nyirokcsomókban nagy számban mutathatók ki különféle tumort infiltráló sejtek: macrophagok, plazmasejtek és regulatorikus T-sejtek. Ez utóbbiak kifejezett immunszuppresszív aktivitással bírnak. A Hodgkinlymphoma az onkohematológia egyik sikertörténetének számít: a betegek mintegy 80-90\%-a kemoterápiával meggyógyítható, és csak $10 \%$ számít problémás, refrakter-relabáló esetnek. E betegek esetén racionális lehetőségnek tünt a PD-1-gátló kezelés alkalmazása. Kimutatták, hogy a Reed-Sternberg-sejtek PD-1-ligandexpressziója más tumorféleségekhez képest is ki kiemelkedően magas [33]. Ennek egyik oka a 9-es kromoszóma p24.1 szakaszának túlmúködése, amely abnormis kópiaszámú PD-1-ligand termelődését eredményezi. A másik fontos tényező a Hodgkin-lymphoma patogenezisében jelentős szerepet játszó Ebstein-Barr-vírus(EBV-) infekcióban keresendő. Az EBV úgynevezett latens membránproteinjei közül az LMPl szerkezetében a CD40 molekulát, míg az LMP2a a B-sejt-receptort utánozza, mindkettő fontos szerepet játszik a Reed-Sternberg-sejtek apoptózisának gátlásában. Emellett az LMPl a PD-1-ligand expresszióját is fokozza $[33,34]$. Nemrégiben két, fázis I vizsgálat is igazolta a PD-1-gátló terápia hatékonyságát többszörösen visszaeső Hodgkin-lymphomás betegeknél.

A myeloma multiplex esetén ígéretes preklinikai adatok számoltak be a PD-1- és PD-ligand-expresszióról a tumorsejteken, illetve az infiltráló mikrokörnyezeti sejteken. A klinikai vizsgálatok eredményei azonban ez idáig csalódást keltőek: legfeljebb a progressziót sikerült gátolni, értékelhető terápiás válasz nem volt [35].

A myeloid eredetú tumorok közül a PD-1-gátló kezelés szempontjából leginkább a myelodysplasiás szindróma tünik érdekesnek, mert a csontvelői blastsejtek jelentős PD-1-ligand-expressziót mutatnak [36]. A jelenleg folyamatban levő fázis I és fázis II vizsgálatok eredményei még nem elérhetőek.

Az immun checkpoint gátló kezelés egy másik racionális alkalmazási lehetőségeként az autológ őssejttranszplantáció (AHSCT) utáni minimális residualis betegség kontrollálása merül fel [37].

Egy fázis I vizsgálatban allogén őssejt-transzplantáció után visszaeső betegek esetén alkalmaztak CTLA-4-gátló kezelést. 29 beteg közül két Hodgkin-lymphomás került 
komplett remisszióba, egy köpenysejtes lymphomás beteg parciális remissziót ért el [38].

$\mathrm{Az}$ allogén transzplantációt követő checkpointot gátló kezelés esetén a leggyakoribb mellékhatás a súlyos és elhúzódó graft versus host betegség (GVHD).

\section{A jövő útja - új immunológiai targetek}

Úgy tünik, hogy a CTLA-4 és a PD-1/PD-Ll blokád csak a jéghegy csúcsát jelentik a potenciális célmolekulák között, amelyek a tumorellenes immunválaszt felerősítve hatékonyan alkalmazhatók a daganatos betegek egy bizonyos csoportjában. Új immun checkpoint inhibitorok lehetséges célpontjai a LAG-3 [39], TIM-3 [40] és VISTA [41], amelyekkel jelenleg is zajlanak preklinikai állatkísérletes és/vagy klinikai fázisban lévő vizsgálatok. A LAG-3 Ig-fúziós proteinnel (IMP321, Immuntep) és antitesttel (BMS-986016) is vannak biztató tapasztalatok, monoterápiában vesesejtes rák esetén [42], metasztatikus emlődaganatokban paclitaxel kemoterápiával kombinációban [43], valamint nivolumabbal kombinációban szolid tumorokban is folynak jelenleg vizsgálatok. A TNF-receptor szupercsaládba tartozó kostimulációs molekulák, az OX40 és $41 \mathrm{BB}$ is célpontként szolgálhatnak. Az anti-4lBB (urelumab, BMS-663513) fázis I/II-es vizsgálatokban ovarialis, vesesejtes daganatokban és melanomában jó eredménnyel zárult, jelenleg is 5 , fázis III vizsgálat zajlik, amelynek eredményeiról az elkövetkező 1-2 évben fogunk értesülni. A harmadik ilyen kostimulációs molekula, az ICOS (inducible co-stimulator) a CD28/B67 család tagja. Az ICOS biomarkerként is szolgálhat, miután anti-CTLA-4-terápia kapcsán az $\mathrm{ICOS}^{+}$effektor T-sejtek száma emelkedik [44].

A checkpointot gátló kezelések effektivitása tovább fokozható a különböző támadáspontú szerek kombinálásával. Az egyik fázis I tanulmányban metasztatizáló vesesejtes rákos betegeknél alkalmazták a tirozinkináz-inhibitor hatású sunitinibet PD-1-gátlóval együtt, és 40$50 \%$-os terápiás válaszarányt tapasztaltak [45]. Ismert, hogy a melanoma kezelésében már engedélyezett BRAFinhibitor vemurafenib fokozza a tumorantigének és az MHC expresszióját, így kézenfekvőnek tünt ezeknek a szereknek a kombinálása az immun checkpoint inhibitorokkal. Sajnos az első próbálkozás nem járt sikerrel: a vemurafenib-ipilimumab kombinációt vizsgáló tanulmányt idő előtt lezárták a hepatotoxikus mellékhatások miatt [46]. Egy új generációs BRAF-gátló szer, a dabrafenib és az ipilimumab kombinációját jelenleg is tesztelik melanomás betegeknél [47]. A kombinációs terápia előnye lehet az is, hogy az immun checkpointot gátlók és az immunológiai célzott terápiák együttes alkalmazása hozzájárul egy olyan „immunológiai memória” kialakulásához, amely a későbbiekben tartósan kontrollálni tudja a tumor növekedését. Ennek alapja az lehet, hogy a célzott terápiás szerek a tumorsejteket elpusztítva számos tumorantigént szabadítanak fel („vakcinációs hatás”), a checkpointot gátlók pedig hozzájárulnak ahhoz, hogy az immunrendszer effektor sejtjei kellő hatékonysággal tudjanak múködni. A különböző pontokon ható „checkpoint”-gátló monoklonális antitestek alkalmazásának eredményeként tehát jó eséllyel a tumor progreszsziója leáll vagy lelassul, amelynek következményeként metasztatikus tumoros állapotokban eddig nem tapasztalt hosszú távú túlélés érhető el.

ONCHU16PR03682-01/Lezárás dátuma: 2016. április 7 .

Anyagi támogatás: Jelen közlemény a Bristol-Myers Squibb felkérésére és támogatásával készült.

Szerzôi munkamegosztás: Mindhárom szerző részt vett a kézirat megírásában és ellenőrzésében. A cikk végleges változatát valamennyi szerző elolvasta és jóváhagyta.

Érdekeltségek: A szerzőknek nincsenek érdekeltségeik.

Az összefoglaló elkészítése a Bristol-Myers Squibb Kft. felkérése alapján készült.

\section{Irodalom}

[1] Vivier, E., Raulet, D. H., Moretta, A., et al.: Innate or adaptive immunity? The example of natural kiler cells. Science, 2011, 331(6013), 44-49.

[2] Kim, R., Emi, M., Tanabe, K.: Cancer immunoediting from immune surveillance to immune escape. Immunology, 2007, $121(1), 1-14$.

[3] Vesely, M. D., Kershaw, M. H., Schreiber, R. D., et al.: Natural innate and adaptive immunity to cancer. Annu. Rev. Immunol., 2011, 29, 235-271.

[4] Borghaei, H., Smith, M. R., Campbell, K. S.: Immunotherapy of cancer. Eur. J. Pharmacol., 2009, 625(1-3), 41-54.

[5] Salama, A. K., Hodi, F. S.: Cytotoxic T-lymphocyte associated antigen-4. Clin. Cancer Res., 2011, 17(14), 4622-4628.

[6] Waterhouse, P., Penninger, J. M., Timms, E., et al.: Lymphoproliferative disorders with early lethality in mice deficient in Ctla-4. Science, 1995, 270(5238), 985-988.

[7] Chen, D. S., Irving, B. A., Hodi, F. S.: Molecular pathways: nextgeneration immunotherapy - inhibiting programmed death-ligand 1 and programmed death-1. Clin. Cancer Res., 2012, 18(24), 6580-6587.

[8] Drake, C. G., Jaffee, E., Pardoll, D. M.: Mechanisms of immune evasion by tumors. Adv. Immunol., 2006, 90, 51-81.

[9] Krüger, C., Greten, T. F., Korangy, F.: Immune based therapies in cancer. Histol. Histopathol., 2007, 22(6), 687-696.

[10] Leach, D. R., Krummel, M. F., Allison, J. P.: Enhancement of antitumor immunity by CTLA-4 blockade. Science, 1996, 271(5256), 1734-1736.

[11] Hodi, F. S., O'Day, S. J., McDermott, D. F., et al.: Improved survival with ipilimumab in patients with metastatic melanoma. N. Engl. J. Med., 2010, 363(8), 711-723.

[12] Van den Eertwegh, A. J., Versluis, J., van den Berg, H. P., et al.: Combined immunotherapy with granulocyte-macrophage colony-stimulating factor-transduced allogenic prostate cancer cells and ipilimumab in patients with metastatic castration-resistant prostate cancer: a phase 1 dose-escalation trial. Lancet Oncol., 2012, 13(5), 509-517. 
[13] Carthon, B. C., Wolchok, J. D., Yuan, J., et al.: Preoperative CTLA-4 blockade: tolerability and immune monitoring in the setting of a presurgical clinical trial. Clin. Cancer Res., 2010, 16(10), 2861-2871.

[14] Postow, M. A., Callahan, M. K., Wolchok, J. D.: Immune checkpoint blockade in cancer therapy. J. Clin. Oncol., 2015, 33(17), 1974-1982.

[15] Robert, C., Thomas, L., Bondarenko, I., et al.: Ipilimumab plus dacarbazine for previously untreated metastatic melanoma. N. Engl. J. Med., 2011, 364(26), 2517-2526.

[16] Ladányi, A., Balatoni, T.: Unblocking antitumor immune re sponse: novel possibilities for the immunotherapy of melanoma. [Az immunválasz „akadálymentesítése”: újabb lehetőségek a melanóma immunterápiájában]. Hung. Oncol., 2013, 57(2), 100-107. [Hungarian]

[17] Schadendorf, D., Hodi, F. S., Robert, C., et al.: Pooled analysis of long-term survival data from phase II and phase III trials of ipilimumab in unresectable or metastatic melanoma. J. Clin. Oncol., 2015, 33(17), 1889-1894.

[18] Wolchok, J. D., Hoos, A., O'Day, S., et al.: Guidelines for the evaluation of immune therapy activity in solid tumors: immune-related response criteria. Clin. Cancer Res., 2009, 15(23), 74127420.

[19] Keir, M. E., Butte, M. J., Freeman, G. J., et al.: PD-1 and its ligands in tolerance and immunity. Annu. Rev. Immunol., 2008, 26, 677-704

[20] Brahmer, J. R., Tykodi, S. S., Chow, L. Q., et al.: Safety and activity of anti-PD-L1 antibody in patients with advanced cancer. N. Engl. J. Med,. 2012, 366(26), 2455-2465

[21] Pardoll, D. M.: The blockade of immune checkpoints in cancer immunotherapy. Nat. Rev. Cancer, 2012, 12(4), 252-264.

[22] Ansell, S. M., Lesokbin, A. M., Borrello, I., et al.: PD-1 blockade with nivolumab in relapsed or refractory Hodgkin's lymphoma. N. Engl. J. Med., 2015, 372(4), 311-319.

[23] Robert, C., Long, G. V., Brady, B., et al.: Nivolumab in previously untreated melanoma without BRAF mutation. N. Engl. J. Med., 2015, 372(4), 320-330.

[24] Powles, T., Eder, J. P., Fine, G. D., et al.: MPDL3280A (anti-PDL1) treatment leads to clinical activity in metastatic bladder cancer. Nature, 2014, 515(7528), 558-562.

[25] Robert, C., Schachter, J., Long, G. V., et al.: Pembrolizumab versus ipilimumab in advanced melanoma. N. Engl. J. Med., 2015 372(26), 2521-2532.

[26] Ribas, A., Puzanov, I., Dummer, R., et al.: Pembrolizumab versus investigator-choice chemotherapy for ipilimumab-refractory melanoma (KEYNOTE-002): a randomised, controlled, phase 2 trial. Lancet Oncol., 2015, 16(8), 908-918.

[27] Topalian, S. L., Sznol, M., McDermott, D. F., et al.: Survival, durable tumor remission, and long-term safety in patients with advanced melanoma receiving nivolumab. J. Clin. Oncol., 2014, 32(10), 1020-1030.

[28] Weber, J. S., D’Angelo, S. P., Minor, D., et al.: Nivolumab versus chemotherapy in patients with advanced melanoma who progressed after anti-CTLA-4 treatment (CheckMate 037): a randomised, controlled, open-label, phase 3 trial. Lancet Oncol., $2015,16(4), 375-384$.

[29] Larkin, J., Chiarion-Sileni, V., Gonzalez, R., et al.: Combined nivolumab and ipilimumab or monotherapy in untreated melanoma. N. Engl. J. Med., 2015, 373(1), 23-34.

[30] Topalian, S. L., Hodi, F. S., Brahmer, J. R., et al.: Safety, activity, and immune correlates of anti-PD- 1 antibody in cancer. N. Engl. J. Med., 2012, 366(26), 2443-2454.

[31] Brahmer, J. R., Drake, C. G., Wollner, I., et al.: Phase I study of single-agent antiprogrammed death-1 (MDX-1106) in refractory solid tumors: safety, clinical activity, pharmacodynamics, and immunologic correlates. J. Clin., Oncol., 2010, 28(19), 31673175
[32] Brahmer, J., Reckamp, K. L., Baas, P., et al.: Nivolumab versus docetaxel in advanced squamous-cell non-small-cell lung cancer. N. Engl. J. Med., 2015, 373(2), 123-135.

[33] Green, M. R., Monti, S., Rodig, S. J., et al.: Integrative analysis reveals selective 9p24.1 amplification, increased PD-1 ligand expression, and further induction via JAK2 in nodular sclerosing Hodgkin lymphoma and primary mediastinal large B-cell lymphoma. Blood, 2010, 116(17), 3268-3277.

[34] Green, M. R., Rodig, S. J., Juszczynski, P., et al.: Constitutive AP-1 activity and EBV infection induce PD-Ll in Hodgkin lymphomas and posttransplant lymphoproliferative disorders: implications for targeted therapy. Clin. Cancer Res., 2012, 18(6), 16111618 .

[35] Lesokbin, A. M., Ansell, S. M., Armand, P., et al.: Preliminary results of a phase I study of nivolumab (BMS-936558) in patients with relapsed or refractory lymphoid malignancies. Blood, 2014, 124(21), 291-291

[36] Yang, H., Bueso-Ramos, C., DiNardo, C., et al.: Expression of PD-L1, PD-L2, PD-1 and CTLA4 in myelodysplastic syndromes is enhanced by treatment with hypomethylating agents. Leukemia, 2014, 28(6), 1280-1288.

[37] Armand, P., Nagler, A., Weller, E. A., et al.: Disabling immune tolerance by programmed death-1 blockade with pidilizumab after autologous hematopoietic stem-cell transplantation for diffuse large B-cell lymphoma: results of an international phase II trial. J. Clin. Oncol., 2013, 31(33), 4199-4206.

[38] Bashey, A., Medina, B., Corringham, S., et al.: CTLA4 blockade with ipilimumab to treat relapse of malignancy after allogeneic hematopoietic cell transplantation. Blood, 2009, 113(7), 15811588 .

[39] Triebel, F., Jitsukawa, S., Baixeras, E., et al.: LAG-3, a novel lymphocyte activation gene closely related to CD4. J. Exp. Med., 1990, 171(5), 1393-1405.

[40] Sakuishi, K., Apetoh, L., Sullivan, J. M., et al.: Targeting Tim-3 and PD-1 pathways to reverse $\mathrm{T}$ cell exhaustion and restore antitumor immunity. J. Exp. Med., 2010, 207(10), 2187-2194

[41] Wang, L., Rubinstein, R., Lines, J. L., et al.: VISTA, a novel mouse Ig superfamily ligand that negatively regulates $\mathrm{T}$ cell responses. J. Exp. Med., 2011, 208(3), 577-592.

[42] Brignone, C., Escudier, B., Grygar, C., et al.: A phase I pharmacokinetic and biological correlative study of IMP321, a novel MHC class II agonist, in patients with advanced renal cell carcinoma. Clin. Cancer Res., 2009, 15(19), 6225-6231.

[43] Brignone, C., Gutierrez, M., Mefti, F., et al.: First-line chemoimmunotherapy in metastatic breast carcinoma: combination of paclitaxel and IMP321 (LAG-3Ig) enhances immune responses and antitumor activity. J. Transl. Med., 2010, 8, 71 .

[44] Liakou, C. I., Kamat, A., Tang, D. N., et al.: CTLA-4 blockade increases IFN- $\gamma$-producing $\mathrm{CD} 4+\mathrm{ICOS}^{\text {hi }}$ cells to shift the ratio of effector to regulatory T cells in cancer patients. Proc. Natl. Acad. Sci. U.S.A., 2008, 105(39), 14987-14992.

[45] Amin, A., Plimack, E. R., Infante, J. R., et al.: Nivolumab (antiPD-1, BMS-936558, ONO-4538) in combination with sunitinib or pazopanib in patients (pts) with metastatic renal cell carcinoma (mRCC). J. Clin. Oncol. ASCO Annual Meeting Proceedings, 2014, 32(15 Suppl.), 5010.

[46] Atefi, M., Avramis, E., Lassen, A., et al.: Effects of MAPK and PI3K pathways on PD-Ll expression in melanoma. Clin. Cancer Res., 2014, 20(13), 3446-3457.

[47] Linnemann, C., van Buuren, M. M., Bies, L., et al.: Highthroughput epitope discovery reveals frequent recognition of neo-antigens by $\mathrm{CD} 4^{+} \mathrm{T}$ cells in human melanoma. Nat. Med., $2015,21(1), 81-85$.

(Szamosi Szilvia dr., Debrecen, Vág u. 36/C, 4031 e-mail: szamosi.szilvi@gmail.com) 